Article

\title{
Atmospheric Monitoring of Methane in Beijing Using a Mobile Observatory
}

\author{
Wanqi Sun ${ }^{1}$, Liangchun Deng ${ }^{2}$, Guoming $\mathrm{Wu}^{3}$, Lin $\mathrm{Wu}^{4}$, Pengfei Han ${ }^{5}$, Yucong Miao ${ }^{6}$ and \\ Bo Yao ${ }^{1, *}$ \\ 1 Meteorological Observation Centre of China Meteorological Administration, 100081 Beijing, China; \\ sunwanqi2008@126.com \\ 2 Center for Environmental Progress, Wuhan 430070, China; lchdeng@163.com \\ 3 Hebei Institute of Meteorological Sciences, Shijiazhuang 050021, China; gumming@sohu.com \\ 4 State Key Laboratory of Atmospheric Boundary Layer Physics and Atmospheric Chemistry, Institute of \\ Atmospheric Physics, Chinese Academy of Sciences, Beijing 100029, China; lin.wu@mail.iap.ac.cn \\ 5 State Key Laboratory of Numerical Modeling for Atmospheric Sciences and Geophysical Fluid Dynamics, \\ Institute of Atmospheric Physics, Chinese Academy of Sciences, Beijing 100029, China; pfhan@mail.iap.ac.cn \\ 5 Chinese Academy of Meteorological Sciences, 100081 Beijing, China; miaoyucong@yeah.net \\ * Correspondence: yaob@cma.gov.cn or yaobont@163.com; Tel.: +86-10-68409554
}

Received: 11 August 2019; Accepted: 12 September 2019; Published: 16 September 2019

\begin{abstract}
Cities have multiple fugitive emission sources of methane $\left(\mathrm{CH}_{4}\right)$ and policies adopted by China on replacing coal with natural gas in recent years can cause fine spatial heterogeneities at the range of kilometers within a city and also contribute to the $\mathrm{CH}_{4}$ inventory. In this study, a mobile observatory was used to monitor the real-time $\mathrm{CH}_{4}$ concentrations at fine spatial and temporal resolutions in Beijing, the most important pilot city of energy transition. Results showed that: several point sources, such as a liquefied natural gas (LNG) power plant which has not been included in the Chinese national greenhouse gas inventory yet, can be identified; the ratio "fingerprints" $\left(\mathrm{CH}_{4}: \mathrm{CO}_{2}\right)$ for an LNG carrier, LNG filling station, and LNG power plant show a shape of " $\mathrm{L}$ "; for city observations, the distribution of $\mathrm{CH}_{4}$ concentration, in the range of 1940-2370 ppbv, had small variations while that in the rural area had a much higher concentration gradient; significant correlations between $\mathrm{CO}_{2}$ and $\mathrm{CH}_{4}$ concentrations were found in the rural area but in the urban area there were no such significant correlations; a shape of " $\mathrm{L}$ " of $\mathrm{CH}_{4}: \mathrm{CO}_{2}$ ratios is obtained in the urban area in wintertime and it is assigned to fugitive emissions from LNG sources. This mobile measurement methodology is capable of monitoring point and non-point $\mathrm{CH}_{4}$ sources in Beijing and the observation results could improve the $\mathrm{CH}_{4}$ inventory and inform relevant policy-making on emission reduction in China.
\end{abstract}

Keywords: mobile measurement; methane; atmospheric concentration; source apportionment

\section{Introduction}

Methane $\left(\mathrm{CH}_{4}\right)$ contributes $\sim 17 \%$ of the radiative forcing by the long-lived greenhouse gases (GHG) [1], with global warming potential (GWP) more than 25 times greater than that of $\mathrm{CO}_{2}$ at a 100-yr time horizon [2]. Its mean annual increase rate witnessed no growth during 1999-2006 but has been increasing again since 2007 [1,3]. Increased emission from anthropogenic sources at mid-latitudes of the northern hemisphere has been considered as one possible main contributor of the recent increase [1,3], while some estimates indicated that China is the world's largest anthropogenic emitter of $\mathrm{CH}_{4}$ [4]. Therefore, it is essential to quantify the anthropogenic sources of $\mathrm{CH}_{4}$ emissions in China and further evaluate their contributions. Cities, especially in Northern China, are generally 
important anthropogenic sources of $\mathrm{CH}_{4}$ [5]. In megacities of China, the total natural gas (NG) consumption increased about seven times over the last 16 years (2000-2016) [6] with policies adopting the replacement of coal with gas launched by the Chinese government $[5,7,8]$. The increasing proportion of NG utilization together with increasing energy demands might lead to complex changes in the spatial and temporal pattern of atmospheric $\mathrm{CH}_{4}$ concentrations, as well as the emission inventory $[5,9,10]$. To better understand the quantitative information, field monitoring at fine spatial and temporal scales in cities is necessary.

Presently, there are several monitoring tools for $\mathrm{CH}_{4}$ emissions, such as satellite remote sensing [11-14], ground station observation [15,16], mobile observation by aircraft [14,17-19] or by car [20-24]. Satellite remote sensing technology is applied for observations mainly at the global or continental scales. Ground-based observation using stationary measurement towers is generally adopted by World Meteorological Organization (WMO) Global Atmosphere Watch (GAW) surface-based global or regional background stations [15,16]. It boasts higher precision than satellite remote sensing, but the high costs of establishment and maintenance have limited the development of an extensive network. Thus, it would be quite difficult to implement such a technology to resolve spatial heterogeneities in a city scale and to track moving sources [25]. In addition, aerial surveys can also offer intensive measurements for the distribution and quantification of sources and sinks of $\mathrm{CH}_{4}$ at city, regional or terrestrial scales [19,26-30], but that kind of measurement is often restricted due to the strict air traffic control in China. A ground-based mobile observatory has more flexibility of use than aircraft, and it has been adopted by several $\mathrm{CH}_{4}$ research projects [9,20-22,24,25,31,32]. The vehicles used include public transit, for example, light-rail platform [25], and ordinary cars [22,31]. Moreover, surveyed fugitive emission covered an extensive range of sources, including combustions [31,33], pipeline [21] and gas infrastructure leaks [22,23], NG developments [20], landfills [22], and oil producing regions [33]. Meanwhile, observed areas are mainly the urban areas [22,23,31,34]. Thus, the mobile ground-based observatory has been tested sufficiently with a wide range of applications to measure point and non-point sources of $\mathrm{CH}_{4}$. However, although a qualitative measurement in Beijing for the purpose to verify the performances of their instrument was conducted [34], comprehensive $\mathrm{CH}_{4}$ concentration of the entire city and the characteristic of different types of sources in Northern China by a mobile observatory has not been reported.

The goal of this work was to set up a ground-based mobile observatory and to measure the concentration of atmospheric $\mathrm{CH}_{4}$ in Beijing with high precision, which has a population of $\sim 19.6$ million and has the largest demand of winter-heating services among cities in China [35]. Beijing is also suffering heavy air pollution $[36,37]$ and taking efforts to replace coal by NG to improve air quality. Nearly all of the coal-fired boilers, including power generating boilers, have been changed into gas ones or air conditioners up to 2017. Studying the concentration of atmospheric $\mathrm{CH}_{4}$ in Beijing could tremendously inform the $\mathrm{CH}_{4}$ inventory and relevant policy-making on GHG emission reduction in China.

\section{Experimental Design}

\subsection{Mobile Observatory for $\mathrm{CH}_{4}$}

The structure of the mobile observatory (MO) used in this work is illustrated in Figure 1. A multi-purpose vehicle (MPV, A800, Chang' an Automobile Group, Chongqing, China) with a sunroof was selected as the mobile platform. The components of this MO included electrical power, a high precision $\mathrm{CH}_{4}$ analyzer, a global positioning system (GPS) receiver and a data acquisition device. The electric power was provided as $220 \mathrm{~V}$ AC via an inverter-charger which was a $12 \mathrm{~V}, 3000 \mathrm{~W}$, pure sine-wave inverter that served a number of different functions (HS-3KRH, Foshan Baykee New Energy Technology Incorporated Company, Foshan, China). The inverter-charger provided 220V AC from a 12V DC supply associated with a battery bank. The battery bank consisted of two lithium ion batteries (300 Ah each), wired in parallel and connected to the inverter-charger. The high precision 
$\mathrm{CH}_{4}$ analyzed was based on a cavity ring-down spectrometer (CRDS) technique (G1301 and 2401, Picarro, Santa Clara, CA, USA). The measurement precision of G1301 was better than $0.7 \mathrm{ppbv}$ for $\mathrm{CH}_{4}$ (5 min average) and that of G2401 was 0.5 ppbv. Ambient air was collected through tubing (1/4" OD, $\sim 2 \mathrm{~m}$ long, Synflex-1300, Aurora, CO, USA) from the inlet $\sim 0.35 \mathrm{~m}$ over the sunroof, or $\sim 2.2 \mathrm{~m}$ above the road surface. Particles were removed by a filter $(0.2 \mu \mathrm{m}$, Ploycap 75, 0.2 PTFE, Buckinghamshire, UK) before it was assessed by the CRDS analyzer, with a measurement interval of approximately $3 \mathrm{~s}$ (G1302) and $1.2 \mathrm{~s}$ (G2401). Considering that the speed of the car was 40 to 80 kilometers per hour, the spatial resolution of this observation method was approximately $10-20 \mathrm{~m}$. Additional technical information for the CRDS analyzer can be found in previous studies [38]. Before and after each observation mission, the CRDS analyzer was calibrated by standard gases which traced to WMO X2004A scale for $\mathrm{CH}_{4}, \mathrm{X} 2007$ scale for $\mathrm{CO}_{2}$, and WMO-2014A scale for $\mathrm{CO}$ to correct the drift of the analyzer. The geographic location of the vehicle platform was obtained by a GPS receiver (BS-70DU, Shenzhen Beitian Communication Co., Ltd., Shenzhen, China), mounted inside the car with an accuracy of approximately $2 \mathrm{~m}$. Data from the CRDS analyzer and GPS receiver were recorded each $1.2 \mathrm{~s}$ by a laptop computer (Tsinghua Tongfang Co., Ltd., Beiing, China, T45PRO-Gcc-21053). The data system time was synchronized with the GPS system time so that the data file and GPS files could be merged in real time.

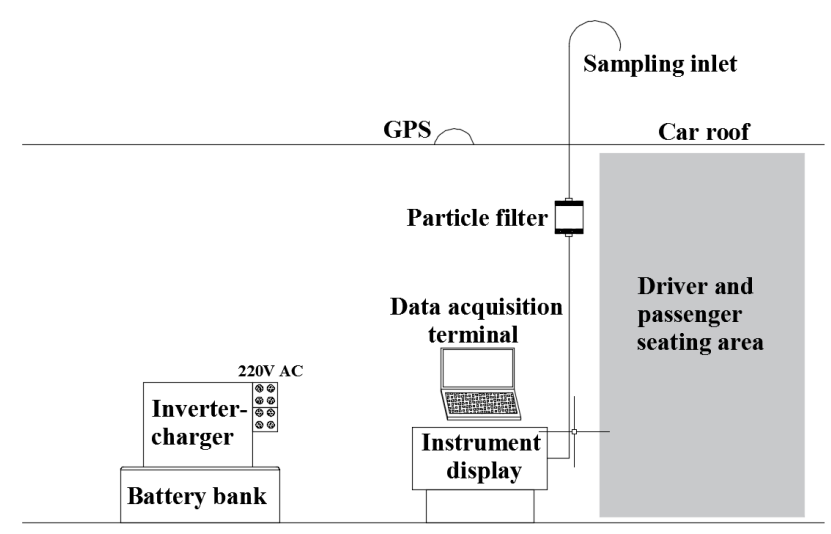

Figure 1. Schematic of the mobile observatory. The viewing angle is from the passenger side of the car.

\subsection{Measurement Routes and Strategies}

Table 1 shows the measurement strategies in Beijing. Firstly, five kinds of point sources, including a liquefied natural gas (LNG) carrier, an LNG station, a residential area, an LNG power plant and a refuse landfill, were surveyed to elucidate their concentration characteristics and ratio "fingerprints" $\left(\mathrm{CH}_{4}: \mathrm{CO}_{2}\right)$. Secondly, the city was surveyed to determine their overall concentration characteristics and to identify the major $\mathrm{CH}_{4}$ emitters. Outward from the city center of Beijing, there are five ring roads that circle the city, the 2nd $(32.7 \mathrm{~km})$, the $3 \mathrm{rd}(48 \mathrm{~km})$, the 4 th $(64 \mathrm{~km})$, the 5 th $(99 \mathrm{~km})$, and the 6 th $(192 \mathrm{~km})$ ring road. The $2 \mathrm{nd}-4 \mathrm{th}$, 5th, and 6 th ring roads are located in the urban, suburban and rural area of the city, respectively. In this study, observations at the 2nd-4th ring roads represented the urban area and the 6th ring road represented the rural area. Climatically, there are four distinctive seasons (spring, summer, autumn, and winter) in Beijing. Heating is necessary over the winter months (annually often from mid-November to mid-March), but not at other times of the year. In this study, "wintertime" and "non-wintertime" were used to characterize the application of heating services. When conducting the monitoring, since the battery used in the measurement can only supply power for $\sim 5 \mathrm{~h}$ to the G1302 in the non-wintertime, the 2nd-4th and 6th ring roads were surveyed on different days and each for three times. For G2401 used in the wintertime, the battery was sufficient for surveys of all the ring roads (2nd-6th) on a single day. All the measurements were conducted during the daytime. The weather conditions and average wind speed, which were directly associated with the diffusion conditions, were also captured from observation, as listed in Table 1. 
Table 1. Measurement routes and strategies.

\begin{tabular}{|c|c|c|c|c|c|c|c|}
\hline $\begin{array}{l}\text { Point Source/Ring } \\
\text { Road }\end{array}$ & $\begin{array}{l}\text { Measurement } \\
\text { Species }\end{array}$ & Date & Time & $\begin{array}{l}\text { Wintertime } \\
(\mathrm{Y} / \mathrm{N})\end{array}$ & Location & Weather & $\begin{array}{l}\text { Mean Wind } \\
\text { Speed }(\mathrm{m} / \mathrm{s})\end{array}$ \\
\hline LNG carrier & $\mathrm{CH}_{4} / \mathrm{CO}_{2}$ & 18th October, 2018 & 10:40-10:55 & $\mathrm{N}$ & Rural & Clear/cloudy & 2.5 \\
\hline LNG station & $\mathrm{CH}_{4} / \mathrm{CO}_{2}$ & 19th October, 2018 & $11: 58-12: 04$ & $\mathrm{~N}$ & Suburban & Cloudy & 1.4 \\
\hline Residential area & $\mathrm{CH}_{4} / \mathrm{CO}_{2}$ & 24th October, 2018 & $17: 12-17: 30$ & $\mathrm{~N}$ & Rural & Cloudy & 1.5 \\
\hline Power plant & $\mathrm{CO}_{2} / \mathrm{CH}_{4} / \mathrm{CO}$ & 21st February, 2019 & $16: 18-16: 50$ & $\mathrm{Y}$ & Suburban & Clear/cloudy & 2.0 \\
\hline Landfill & $\mathrm{CH}_{4} / \mathrm{CO}_{2} / \mathrm{CO}$ & 21st February, 2019 & $17: 00-17: 35$ & $\mathrm{Y}$ & Suburban & Clear/cloudy & 2.0 \\
\hline 2nd-4th & $\mathrm{CH}_{4} / \mathrm{CO}_{2}$ & 26th September, 2018 & $12: 30-17: 30$ & $\mathrm{~N}$ & Urban & Cloudy & 2.3 \\
\hline 2nd-4th & $\mathrm{CH}_{4} / \mathrm{CO}_{2}$ & 23rd October, 2018 & 14:03-19:12 & $\mathrm{N}$ & Urban & Clear & 2.4 \\
\hline 2nd-4th & $\mathrm{CH}_{4} / \mathrm{CO}_{2}$ & 30th October, 2018 & 12:45-18:19 & $\mathrm{N}$ & Urban & Clear & 2.3 \\
\hline 6th & $\mathrm{CH}_{4} / \mathrm{CO}_{2}$ & 28th September,2018 & 10:24-13:39 & $\mathrm{N}$ & Rural & Cloudy & 2.0 \\
\hline 6th & $\mathrm{CH}_{4} / \mathrm{CO}_{2}$ & 18th October, 2018 & $14: 29-16: 17$ & $\mathrm{~N}$ & Rural & Clear & 2.5 \\
\hline 6th & $\mathrm{CH}_{4} / \mathrm{CO}_{2}$ & 24th October, 2018 & 14:39-18:39 & $\mathrm{N}$ & Rural & Cloudy & 1.5 \\
\hline 2nd-6th & $\mathrm{CH}_{4} / \mathrm{CO}_{2} / \mathrm{CO}$ & 20th February, 2019 & 09:22-18:18 & $\mathrm{Y}$ & All & Clear & 1.5 \\
\hline
\end{tabular}

\subsection{Data Analysis}

According to the observation log, invalid data were identified and flagged. The concentration data of $\mathrm{CH}_{4}$ and $\mathrm{CO}_{2}$ were calibrated by standard gases, as was the time data for the delayed response of the sampling system for $55 \mathrm{~s}$. Finally, the $\mathrm{CH}_{4}$ concentration data, along with the meteorological data obtained from the meteorological stations adjacent to the observed areas, were combined with GPS data to generate spatial information data using the Arc GIS software.

To understand the correlation of $\mathrm{CH}_{4}$ and $\mathrm{CO}_{2}$ for fugitive emissions and city-scale emissions of Beijing, the minimum concentration value was subtracted from each survey as background to create a dataset of differences, or "enhanced" (e) concentrations which means the observed concentration minus background values and represent the enhancement for a gas species $\left(\mathrm{eCO}_{2}, \mathrm{eCH}_{4}\right)$. The data processing method refers to what Hurry et al. used in the observation activity in oil producing regions in North America [33].

\section{Result and Discussion}

\subsection{Point Source Observation in Beijing}

Figure 2 shows map transections of $\mathrm{CH}_{4}$ and ratio "fingerprints" $\left(\mathrm{CH}_{4}: \mathrm{CO}_{2}\right)$ of five point sources in Beijing. Figure 2A shows the screening result of an LNG carrier. A hotspot was captured with peak concentration up to 2524 ppbv. Its $\mathrm{CH}_{4}: \mathrm{CO}_{2}$ ratios show a shape of "L" of high $\mathrm{CH}_{4}$ values versus low $\mathrm{CO}_{2}$ values (slope $=0.02, \mathrm{r}=0.82, p<0.001$ ), and high $\mathrm{CO}_{2}$ concentrations versus low $\mathrm{CH}_{4}$ concentrations (slope $=0.0002, r=0.43, p<0.001$ ). This is similar to the survey result of gas regulator stations [22]. The slope 0.0002 could be used to deduce that it mainly originated from the vehicle exhaust [33] and the slope 0.02 was associated with the release of $\mathrm{CH}_{4}$ from storage facilities in the carrier [22].

Figure 2B presents the $\mathrm{CH}_{4}$ map transection of an LNG filling station in the suburban area. One hotspot with maximum concentration $4777 \mathrm{ppbv}$ appeared at the site adjacent to the LNG storage facility in the station while another with $2799 \mathrm{ppbv}$ on the side of a working gas gun. Its $\mathrm{CH}_{4}: \mathrm{CO}_{2}$ ratios also shows a shape of " $\mathrm{L}$ " $\left(\mathrm{CH}_{4}: \mathrm{CO}_{2}=0.18\right.$ and 0.001$)$. The slope 0.18 is higher than 0.02 shown in Figure 2A by one order of magnitude which describes a different type of source profile, although it may be specific to the time and location.

Figure $2 \mathrm{C}$ shows the $\mathrm{CH}_{4}$ map transection of a residential area at cooking time using gas for cooking. One hotspot with peak concentration $3436 \mathrm{ppbv}$ emerged in the residential area while another one with maximum concentration $3448 \mathrm{ppbv}$ on the side of it. The $\mathrm{CH}_{4}: \mathrm{CO}_{2}$ ratios of the two hotspots are $0.014(\mathrm{r}=0.9, p<0.001)$ and $0.007(\mathrm{r}=0.82, p<0.001)$. They may associate with the leakage of $\mathrm{CH}_{4}$ pipelines or combustion devices [22,33].

Figure 2D shows the survey result of an LNG power plant. The MO circled the plant for three times and the concentration distributions obtained were similar, namely, concentrations being low in the upwind side and high in the downwind side. The $\mathrm{CH}_{4}: \mathrm{CO}_{2}$ ratios also reflected a characteristic " $\mathrm{L}$ " pattern $(-0.02, r=-0.55, p<0.001$ and $3.8, r=0.5, p<0.001)$, but the " $\mathrm{L}$ " was different from Figure $2 \mathrm{~A}, \mathrm{~B}$ 
and one of the slopes was negative. This may have been associated with the relationship between the $\mathrm{CH}_{4}$ supply and the combustion efficiency of the boiler.

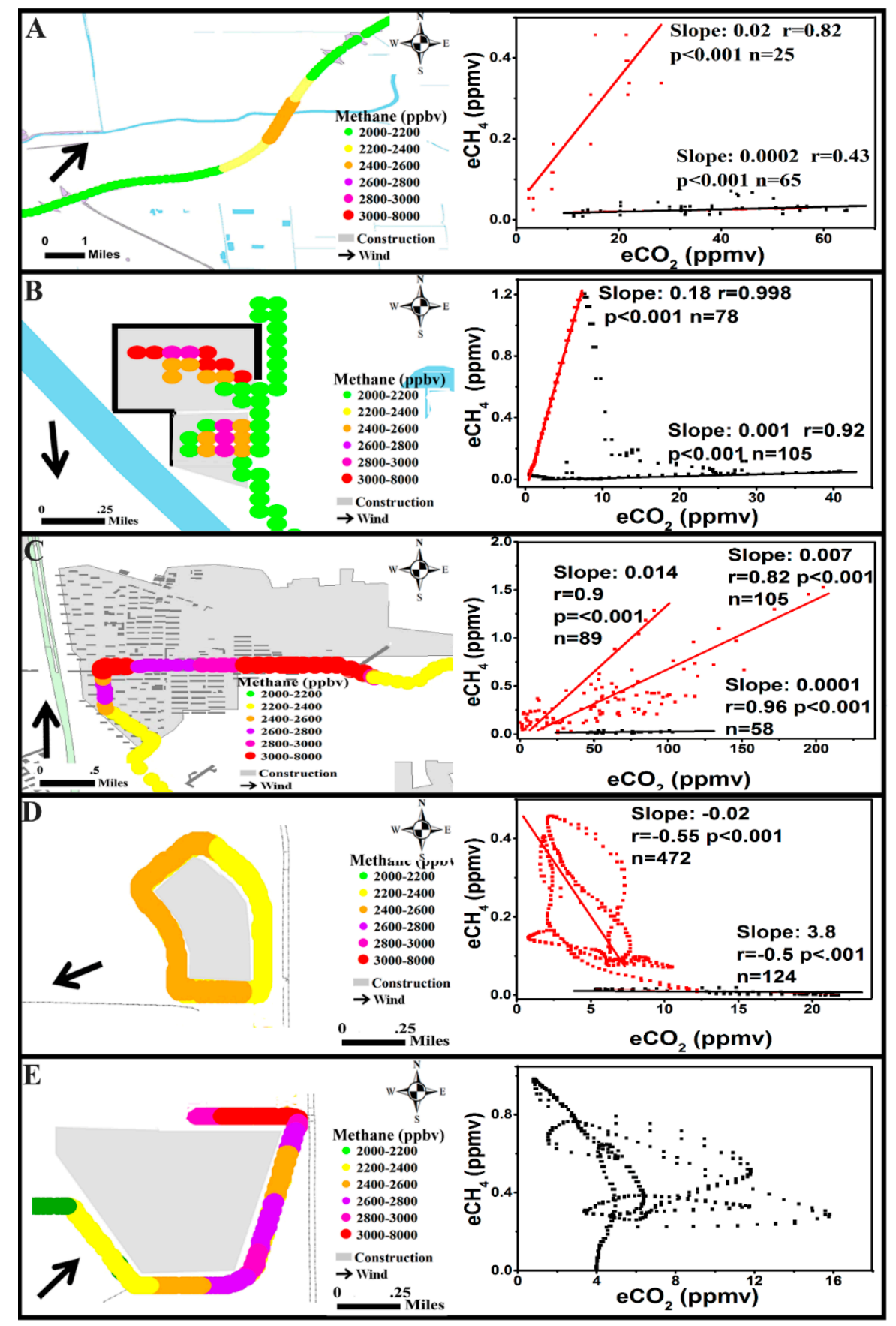

Figure 2. $\mathrm{CH}_{4}$ concentration map and ratio "fingerprints" $\left(\mathrm{CH}_{4}: \mathrm{CO}_{2}\right)$ of five point sources as a function of location: (A) an liquified natural gas (LNG) carrier; (B) an LNG filling station; (C) a residential area; (D) an LNG power station; (E) a refuse landfill. In A-D, the red dots represent the measurements of which high levels of $\mathrm{CH}_{4}$ were associated with low $\mathrm{CO}_{2}$ concentrations and black dots represent that the measurements where high $\mathrm{CO}_{2}$ concentrations were associated with low $\mathrm{CH}_{4}$ concentrations. The red and black lines are the linear regression results corresponding to the two groups of dots, respectively. The linear regressions are as the basis of ordinary least squares.

Figure 2E shows the survey result of a refuse landfill. High concentration was in the downwind east and northeast of site. The wind distribution and the existence of the $\mathrm{CH}_{4}$ disposing plant located 
in the east of the landfill have contributed to such concentration distribution. The characteristic of $\mathrm{CH}_{4}: \mathrm{CO}_{2}$ ratios were complex, which were different to the other four sources mentioned above. The complexity may have generated from the multiple $\mathrm{CH}_{4}$ sources in the landfill, such as the landfill itself with the biological processes, the landfill leachate, the collecting pipelines of $\mathrm{CH}_{4}$, the burning of the collected $\mathrm{CH}_{4}$ in the disposing plant, and the garbage trucks.

In short, the MO had enough temporal and spatial resolution to identify the typical point sources of $\mathrm{CH}_{4}$ in both urban and rural areas in Beijing. The ratio "fingerprints" for the point sources using LNG all showed a characteristic " $\mathrm{L}$ " pattern, which was useful to distinguish different $\mathrm{CH}_{4}$ sources in the city.

\subsection{City Observation in the Non-Wintertime Period}

Figure 3 shows results of the urban (the 2nd-4th ring roads) and rural area (the 6th ring road) of Beijing in non-wintertime. The boxplot method was used to show the distribution characteristics of the observed $\mathrm{CH}_{4}$ concentration data, whose statistical results are shown in Table 2. It includes the values of minimum, maximum, median, upper quartile $(\mathrm{Q} 1)$, lower quartile $(\mathrm{Q} 2)$, inter-quartile range (IQR), and maximum outlier and number of valid data for each measurement. Note that the outliers are the values outside of the box body (less than Q1 $-1.5 \times$ IQR or higher than Q3 + 1.5 $\times$ IQR).

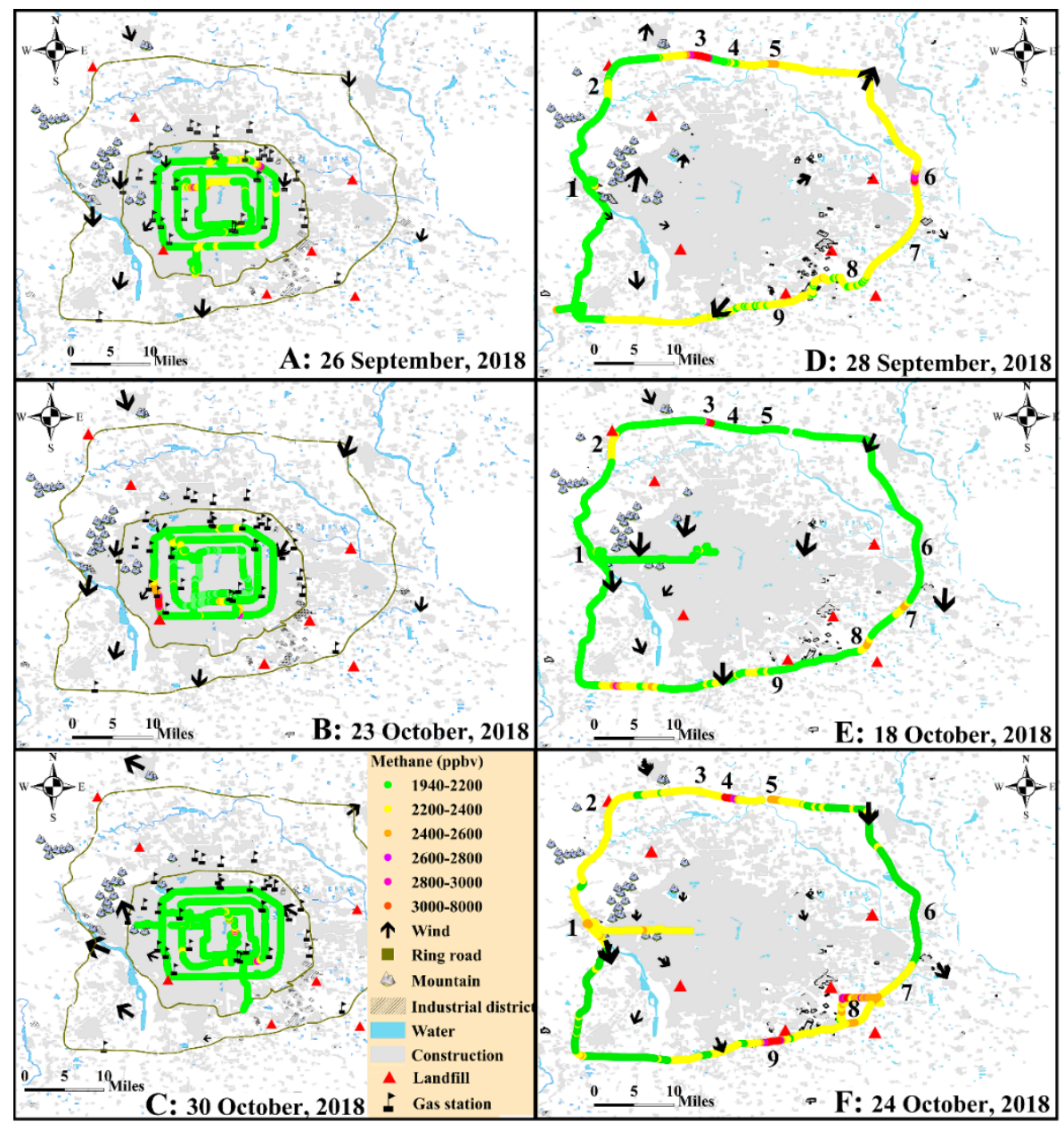

Figure 3. $\mathrm{CH} 4$ concentration maps of the 2 nd -4 th and the 6 th ring roads as a function of location in non-wintertime. Note: The directions and magnitudes of arrows show the wind directions and speeds when the meteorological station was at these locations. 
Table 2. Statistics analysis for $\mathrm{CH}_{4}$ concentration data of the urban and rural area.

\begin{tabular}{|c|c|c|c|c|c|c|c|c|c|}
\hline & Figure & $\underset{(p p b v)}{\text { Minimum }}$ & $\underset{(p p b v)}{\text { Maximum }}$ & $\begin{array}{c}\text { Median } \\
\text { (ppbv) }\end{array}$ & $\begin{array}{c}\mathrm{Q1}^{1)} \\
(\mathrm{ppbv})\end{array}$ & $\begin{array}{c}\mathrm{Q}^{1)} \\
(\mathrm{ppbv})\end{array}$ & $\begin{array}{l}\mathrm{IQR}^{2)} \\
(\mathrm{ppbv})\end{array}$ & $\begin{array}{c}\text { Maximum } \\
\text { Outlier (ppbv) }\end{array}$ & $\mathbf{N}^{3}$ \\
\hline \multirow{4}{*}{ Urban } & $3 \mathrm{~A}$ & 2015 & 2370 & 2127 & 2082 & 2198 & 116 & 3047 & 15,760 \\
\hline & $3 \mathrm{~B}$ & 1956 & 2244 & 2056 & 2011 & 2104 & 93 & 3182 & 3243 \\
\hline & $3 C$ & 1940 & 2050 & 1986 & 1973 & 2004 & 31 & 2864 & 3016 \\
\hline & 4 & 2059 & 2248 & 2145 & 2169 & 2116 & 53 & 2436 & 13,793 \\
\hline \multirow{4}{*}{ Rural } & $3 \mathrm{D}$ & 2049 & 2515 & 2221 & 2138 & 2290 & 152 & 7657 & 12,339 \\
\hline & $3 \mathrm{E}$ & 2016 & 2238 & 2126 & 2103 & 2158 & 55 & 4441 & 2641 \\
\hline & $3 \mathrm{~F}$ & 2074 & 2467 & 2255 & 2197 & 2307 & 110 & 4216 & 2502 \\
\hline & 4 & 1953 & 2276 & 2009 & 1979 & 2098 & 119 & 2789 & 8143 \\
\hline
\end{tabular}

Q: quartile; IQR: inter-quartile range; N: number of valid data.

Figure $3 \mathrm{~A}-\mathrm{C}$ present the $\mathrm{CH}_{4}$ map transections of the urban area on 26 September, 23 October, and 30 October, 2018, respectively. Generally, the concentrations for the three survey days mainly ranged from 1940 to $2370 \mathrm{ppbv}$, which are obviously higher than that reported in 2000 (1870-2000 ppbv) [39] in the urban area and similar to that measured during 2009-2014 by WMO/GAW Shangdianzi regional background station (1850-2400 ppbv) which is $100 \mathrm{~km}$ away from the urban area ${ }^{16}$. The concentration gradient was relatively small, implying that the urban area might be treated as a typical non-point source of $\mathrm{CH}_{4}$. However, some hotspots, whose concentration were higher than $2800 \mathrm{ppbv}$, were observed during all surveys with different locations, indicating that some intermittent or mobile fugitive leaks may exist, for example, underground transmission, distribution pipelines or usages by the residents [31].

Figure 3D-F show the $\mathrm{CH}_{4}$ map transections of the rural area on 28 September, 18 October, and 24 October, 2018, respectively. The concentrations for the three surveys mainly distributed between 2016-2515 ppbv, which were notably higher than those of the urban area mentioned above. The dispersion of these data was also higher than those of the urban area through comparing the inter-quartile range (IQRs). There were obviously concentration gradients up to several hundred ppbv, in Figure 3D,F, but not in Figure 3E. Higher concentrations were observed both in areas upwind and downwind of urban Beijing, which revealed that the local emission might be the main impact factor rather than the $\mathrm{CH}_{4}$ emission from urban area. Moreover, eight notable hotspots were captured. The concentrations of hotspot $1(2400-2600 \mathrm{ppbv})$ were just slightly higher than its surroundings (2000-2400 ppbv). It was identified to be a LNG power plant, which was a source not included by the methane inventory of China [5], through the method mentioned in Section 3.1 and the field investigation. The hotspot 2 (2200-2400 ppbv) could be recognized in all three surveys, mainly due to the nearby landfill. Hotspot 3 emerged with the maximum concentration 7657 ppbv in Figure 3D,E. It might have been a stationary fugitive source, such as NG pipeline leak, which existed before 28 September, 2018 and was presumably remediated between 18 October, and 24 October, 2018. Hotspots 4-9 emerged randomly in the three figures. Hotspot 7 was identified as the LNG carrier (Figure 2A) and hotspot 8 was a residential area (Figure 2C). But the sources for hotspots $4-6$ and 9 were not identified. According to their characteristic, they were speculated to be associated with mobile gas carriers or intermittent sources, such as leakages of underground transmission and distribution pipelines.

\subsection{City Observation in the Wintertime Period}

Figure 4 shows the result of survey on 20 February, 2019 which was in the wintertime. The statistical results of the urban and rural area are presented in Table 2. The $\mathrm{CH}_{4}$ concentrations for the urban area (the 2nd-4th ring roads) were mainly in the range of 2059-2248 ppbv and it was similar to that obtained in the non-wintertime. The $\mathrm{CH}_{4}$ concentrations for the rural area (the 6th ring road) were mainly between 1953-2276 ppbv, lower than that obtained in the non-wintertime. There was a remarkable concentration gradient. Higher concentrations were found in the southwest area and lower in the northeast part. Meanwhile, concentrations were much higher in the downwind area than the upwind area, similar to the observation result in urban area of eastern Germany [23]. Several hotspots were observed and their identifications were similar to that discussed in Section 3.2. 


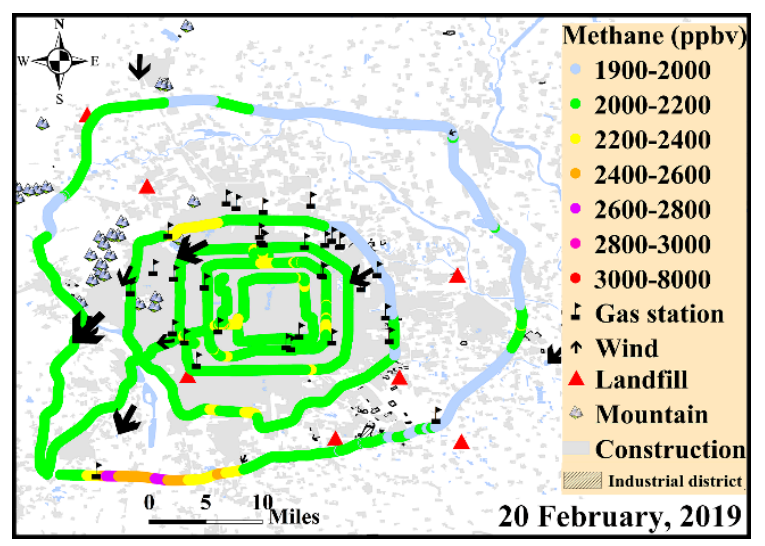

Figure 4. $\mathrm{CH}_{4}$ concentration map as a function of location in wintertime.

Figure 5A-D shows the relationship between the $\mathrm{CH}_{4}$ and $\mathrm{CO}_{2}$ concentrations measured in non-winter and wintertime. Regression analysis was used to determine the $\mathrm{CH}_{4} / \mathrm{CO}_{2}$ ratio. The regression coefficients (r) in Figure 5A,C were both quite small, demonstrating that the correlation of $\mathrm{CH}_{4}$ and $\mathrm{CO}_{2}$ enhanced concentrations in the urban of Beijing was quite weak, in contrast to the significant correlation in research conducted in Nanjing [40]. Our study provided high spatial resolution data of $\mathrm{CH}_{4}$ and $\mathrm{CO}_{2}$, while a fixed sensor is used by the study in Nanjing on a higher floor of a building, which might explain that stronger correlations between $\mathrm{CH}_{4}$ and $\mathrm{CO}_{2}$ were observed since they were sensitive to more mixed air within the footprint of their sensor. In Figure 5C, the red outliers are with high $\mathrm{CH}_{4}$ concentrations but small or even negative $\mathrm{CO}_{2}$ elevation makes the whole figure a shape of "L". This " $L$ " pattern was similar to that of the $L N G$ point sources, such as the passing-by LNG carrier, the LNG filling station, or the LNG power plant (see Figure 2A,B,D, respectively), which indicated that LNG sources might have contributed to $\mathrm{CH}_{4}$ enhancement in this survey. The enhanced $\mathrm{CH}_{4}$ concentrations had significant correlation $(p<0.001)$ with $\mathrm{CO}_{2}$ enhancements in the rural area with regression coefficient (r) of 0.5 and 0.79 in Figure 5B,D, respectively. The regression slope $\left(\mathrm{CH}_{4}: \mathrm{CO}_{2}\right)$ for the rural area was 0.003 in non-wintertime and 0.004 in wintertime. The slope 0.004 was comparable to that obtained in Boulder [41] and Indianapolis [30], USA. It should be noted that different methodologies were applied in these studies and the differences introduced by methodologies were not considered.

$\mathrm{CO}$ concentrations were also observed in wintertime. Figure $5 \mathrm{E}, \mathrm{F}$ shows the relationship between the $\mathrm{CH}_{4}$ and $\mathrm{CO}$ concentrations in wintertime. In Figure 5E, similar to that of $\mathrm{CH}_{4} / \mathrm{CO}_{2}$ in Figure $5 \mathrm{~A}, \mathrm{C}$, the regression coefficients ( $\mathrm{r}$ ) was quite small, revealing that the correlation of $\mathrm{CH}_{4}$ and $\mathrm{CO}$ enhanced concentrations in the urban of Beijing was quite weak. Meanwhile, obvious $\mathrm{CH}_{4}$ fugitive emissions could be seen (red dots). This revealed that the $\mathrm{CH}_{4}$ sources were complicated in the urban area. Shown in Figure 5F, the enhanced $\mathrm{CH}_{4}$ concentrations had significant correlation $(p<0.001)$ with $\mathrm{CO}$ enhancements in the rural area with a regression coefficient $(\mathrm{r})$ of 0.87 , which was similar to the significant correlation of $\mathrm{CH}_{4}$ and $\mathrm{CO}_{2}$ shown in Figure $5 \mathrm{~B}$,D. This indicated the high $\mathrm{CO}_{2} / \mathrm{CH}_{4} / \mathrm{CO}$ concentrations in winter might have been influenced by combustion or by well mixed anthropogenic emissions from other sources in Beijing city. 

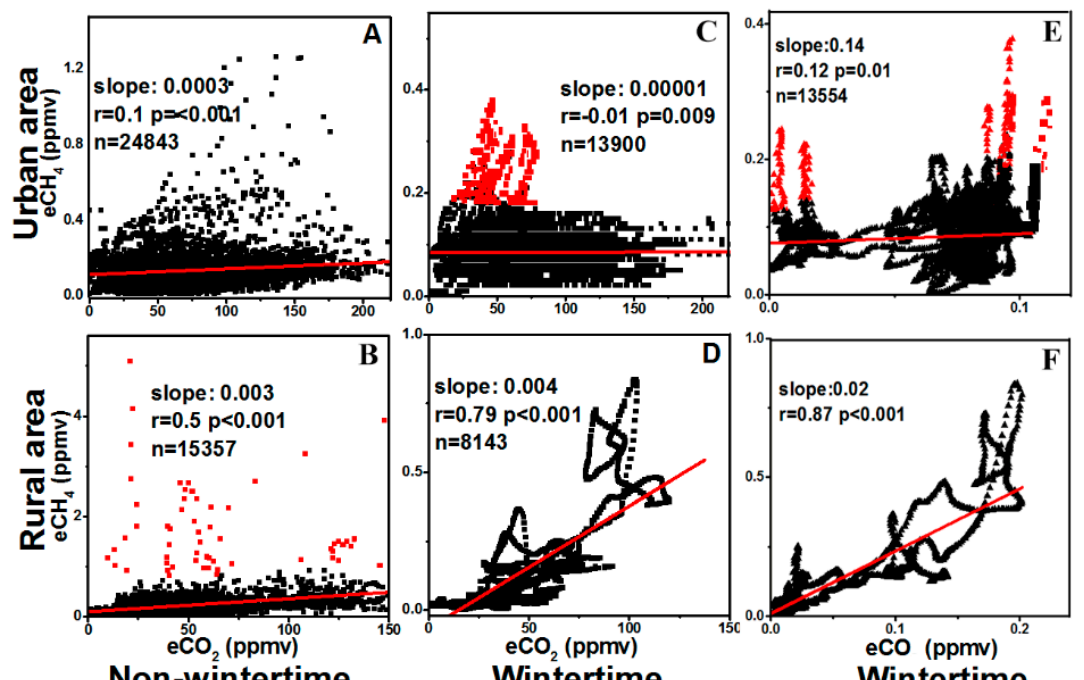

Non-wintertime

Wintertime

Wintertime

Figure 5. Correlation analysis of $\mathrm{CH}_{4}$ and $\mathrm{CO}_{2}$ enhanced concentrations in the non-wintertime in the urban area (A) and in the rural area (B) and in the wintertime in the urban area $(\mathbf{C})$ and in the rural area (D) and of $\mathrm{CH}_{4}$ and $\mathrm{CO}$ enhanced concentrations in the wintertime in the urban area (E) and in the rural area (F). For the rural area measurement, three measurement data were merged for each figure. The slope, the regression coefficient ( $\mathrm{r}$ ) and the confidence level $(p)$, the number of observations (n), are also shown. Note that the scales are different for urban and rural areas. The red lines are the linear regression results. In $\mathrm{B}, \mathrm{C}$, and $\mathrm{E}$, the red dots represent the measurements of obvious fugitive $\mathrm{CH}_{4}$ and they were not used in the regression analysis.

\section{Conclusions}

A mobile observatory was applied to real-time monitor the $\mathrm{CH}_{4}$ concentration of point and non-point (city) sources in Beijing. The results indicated that this mobile measurement methodology has enough temporal and spatial resolution to identify typical $\mathrm{CH}_{4}$ sources in Beijing. The ratio "fingerprints" $\left(\mathrm{CH}_{4}: \mathrm{CO}_{2}\right)$ for the LNG carrier, LNG filling station, and LNG power plant showed a characteristic "L" pattern which may reveal typical point sources with LNG leakage. For city observations in non-wintertime, the $\mathrm{CH}_{4}$ concentrations were in the range of 1940-2370 ppbv and those in the rural area were 2016-2515 ppbv. Several fugitive point sources, including LNG power plant and landfill, were successfully identified in the rural measurement. As for city observation in wintertime, the $\mathrm{CH}_{4}$ concentrations were mainly in the range of 2059-2248 ppbv, which was comparable to that in the non-wintertime observations, while concentrations in the rural area (1953-2276 ppbv) also had an obvious concentration gradient. According to the correlation analysis, the $\mathrm{CH}_{4}$ and $\mathrm{CO}_{2}$ enhanced concentration showed significant correlation in the rural area, but not in the urban area. A shape of " $\mathrm{L}$ " was obtained and it suggested fugitive emissions from the NG sources in wintertime. Further attempts of $\mathrm{CH}_{4}$ emission study by inverse modeling on a city scale would help understanding the observed signals. Similar studies report the quantification of $\mathrm{CH}_{4}$ emission by mobile measurement platform such as airplanes $[42,43]$.

Author Contributions: Conceptualization, B.Y.; Methodology, B.Y. and W.-Q.S.; Software, W.-Q.S. and B.Y.; Validation, B.Y. and W.-Q.S.; Formal Analysis, W.-Q.S. and B.Y.; Investigation, W.-Q.S.; Resources, B.Y.; Data Curation, W.-Q.S.; Writing-Original Draft Preparation, W.-Q.S.; Writing-Review \& Editing, L.-C.D., B.Y., L.W., P.-F.H., and Y.-C.M.; Visualization, W.-Q.S. and G.-M.W.; Supervision, B.Y.; Project Administration, W.-Q.S.; Funding Acquisition, B.Y.

Funding: This work was supported by the National Key R\&D Program of China (2017YFB0504000) and the National Natural Science Foundation of China (NO. 41705134 and 41575114).

Acknowledgments: We thank National Oceanic and Atmospheric Administration (NOAA)/Earth System Research Laboratory (ESRL) for providing tertiary standard gases. We also thank Hongyang Wang for calibrating the instruments used in the study. 
Conflicts of Interest: The authors declare no conflict of interest. The funders had no role in the design of the study; in the collection, analyses, or interpretation of data; in the writing of the manuscript, and in the decision to publish the results.

\section{References}

1. WMO. Greenhouse Gas Bulletin: The State of Greenhouse Gases in the Atmosphere Based on Global Observations through 2017; WMO: Geneva, Switzerland, 2017.

2. Solomon, S.; Qin, D.; Manning, M.; Averyt, K.; Marquis, M. Climate Change 2007-The Physical Science Basis: Working Group I Contribution to the Fourth Assessment Report of the IPCC; Cambridge University Press: Cambridge, UK, 2007; Volume 4.

3. Fletcher, S.E.M.; Schaefer, H. Rising methane: A new climate challenge. Science 2019, 364, 932-933. [CrossRef] [PubMed]

4. Korsbakken, J.I.; Peters, G.P.; Andrew, R.M. Uncertainties around reductions in China's coal use and $\mathrm{CO}_{2}$ emissions. Nat. Clim. Chang. 2016, 6, 687-691. [CrossRef]

5. Cai, B.f.; Zhang, J.J.; Dong, H.J.; Yao, B. The Illustrated Handbook of Greenhouse Gas Emissions from Chinese Cities 2015; China Environmental Science Press: Beijing, China, 2019.

6. MOHURD-Ministry of Housing and Urban-Rural Development of the People's Republic of China. China Urban Construction Statistical Yearbook 2013-2017; MOHURD: Beijing, China, 2018.

7. Cui, Y.; Zhang, W.; Wang, C.; Streets, D.G.; Xu, Y.; Du, M.; Lin, J. Spatiotemporal dynamics of $\mathrm{CO}_{2}$ emissions from central heating supply in the North China Plain over 2012-2016 due to natural gas usage. Appl. Energy 2019, 241, 245-256. [CrossRef]

8. Shen, G.; Ru, M.; Du, W.; Zhu, X.; Zhong, Q.; Chen, Y.; Shen, H.; Yun, X.; Meng, W.; Liu, J. Impacts of air pollutants from rural Chinese households under the rapid residential energy transition. Nat. Commun. 2019, 10, 1-8. [CrossRef] [PubMed]

9. McKain, K.; Down, A.; Raciti, S.M.; Budney, J.; Hutyra, L.R.; Floerchinger, C.; Herndon, S.C.; Nehrkorn, T.; Zahniser, M.S.; Jackson, R.B. Methane emissions from natural gas infrastructure and use in the urban region of Boston, Massachusetts. Proc. Natl. Acad. Sci. USA 2015, 112, 1941-1946. [CrossRef] [PubMed]

10. Alvarez, R.A.; Zavala-Araiza, D.; Lyon, D.R.; Allen, D.T.; Barkley, Z.R.; Brandt, A.R.; Davis, K.J.; Herndon, S.C.; Jacob, D.J.; Karion, A. Assessment of methane emissions from the US oil and gas supply chain. Science 2018, 361, 186-188. [PubMed]

11. Butz, A.; Guerlet, S.; Hasekamp, O.; Schepers, D.; Galli, A.; Aben, I.; Frankenberg, C.; Hartmann, J.M.; Tran, H.; Kuze, A. Toward accurate $\mathrm{CO}_{2}$ and $\mathrm{CH}_{4}$ observations from GOSAT. Geophys. Res. Lett. 2011, 38, 130-137. [CrossRef]

12. Buchwitz, M.; Reuter, M.; Bovensmann, H.; Pillai, D.; Heymann, J.; Schneising, O.; Rozanov, V.; Krings, T.; Burrows, J.; Boesch, H. Carbon Monitoring Satellite (CarbonSat): Assessment of atmospheric $\mathrm{CO}_{2}$ and $\mathrm{CH}_{4}$ retrieval errors by error parameterization. Atmos. Meas. Tech. 2013, 6, 3477-3500. [CrossRef]

13. Saitoh, N.; Touno, M.; Hayashida, S.; Imasu, R.; Shiomi, K.; Yokota, T.; Yoshida, Y.; Machida, T.; Matsueda, H.; Sawa, Y. Comparisons between $\mathrm{XCH}_{4}$ from GOSAT shortwave and thermal infrared spectra and aircraft $\mathrm{CH}_{4}$ measurements over Guam. SOLA 2012, 8, 145-149. [CrossRef]

14. Xiong, X.; Barnet, C.D.; Zhuang, Q.; Machida, T.; Sweeney, C.; Patra, P.K. Mid-upper tropospheric methane in the high Northern Hemisphere: Spaceborne observations by AIRS, aircraft measurements, and model simulations. J. Geophys. Res. Atmos. 2010, 115, 1-15. [CrossRef]

15. Fang, S.X.; Zhou, L.X.; Masarie, K.A.; Xu, L.; Rella, C.W. Study of atmospheric $\mathrm{CH}_{4}$ mole fractions at three WMO/GAW stations in China. J. Geophys. Res. Atmos. 2013, 118, 4874-4886. [CrossRef]

16. Fang, S.-X.; Tans, P.P.; Dong, F.; Zhou, H.; Luan, T. Characteristics of atmospheric $\mathrm{CO}_{2}$ and $\mathrm{CH}_{4}$ at the Shangdianzi regional background station in China. Atmos. Environ. 2016, 131, 1-8. [CrossRef]

17. Nakazawa, T.; Sugawara, S.; Inoue, G.; Machida, T.; Makshyutov, S.; Mukai, H. Aircraft measurements of the concentrations of $\mathrm{CO}_{2}, \mathrm{CH}_{4}, \mathrm{~N}_{2} \mathrm{O}$, and $\mathrm{CO}$ and the carbon and oxygen isotopic ratios of $\mathrm{CO}_{2}$ in the troposphere over Russia. J. Geophys. Res. Atmos. 1997, 102, 3843-3859. [CrossRef] 
18. Gerilowski, K.; Tretner, A.; Krings, T.; Buchwitz, M.; Bertagnolio, P.P.; Belemezov, F.; Erzinger, J.; Burrows, J.P.; Bovensmann, H. MAMAP-A new spectrometer system for column-averaged methane and carbon dioxide observations from aircraft: Instrument description and performance analysis. Atmos. Meas. Tech. 2011, 4, 215-243. [CrossRef]

19. Karion, A.; Sweeney, C.; Wolter, S.; Newberger, T.; Chen, H.; Andrews, A.; Kofler, J.; Neff, D.; Tans, P. Long-term greenhouse gas measurements from aircraft. Atmos. Meas. Tech. 2013, 6, 511-526. [CrossRef]

20. Atherton, E.; Risk, D.; Fougère, C.; Lavoie, M.; Marshall, A.; Werring, J.; Williams, J.P.; Minions, C. Mobile measurement of methane emissions from natural gas developments in northeastern British Columbia, Canada. Atmos. Chem. Phys. 2017, 17, 12405-12420. [CrossRef]

21. LeIfer, I.; Melton, C.; Manish, G.; Leen, B. Mobile Monitoring of Methane Leakage; Gases and Instrumentation, Gases and Instrumentation International: Wellesley Hills, MA, USA, 2014.

22. Lamb, B.K.; McManus, J.B.; Shorter, J.H.; Kolb, C.E.; Mosher, B.; Harriss, R.C.; Allwine, E.; Blaha, D.; Howard, T.; Guenther, A. Development of atmospheric tracer methods to measure methane emissions from natural gas facilities and urban areas. Environ. Sci. Technol. 1995, 29, 1468-1479. [CrossRef] [PubMed]

23. Shorter, J.H.; Mcmanus, J.B.; Kolb, C.E.; Allwine, E.J.; Lamb, B.K.; Mosher, B.W.; Harriss, R.C.; Partchatka, U.; Fischer, H.; Harris, G.W. Methane emission measurements in urban areas in eastern Germany. J. Atmos. Chem. 1996, 24, 121-140. [CrossRef]

24. Lamb, B.K.; Cambaliza, M.O.; Davis, K.J.; Edburg, S.L.; Ferrara, T.W.; Floerchinger, C.; Heimburger, A.M.; Herndon, S.; Lauvaux, T.; Lavoie, T. Direct and indirect measurements and modeling of methane emissions in Indianapolis, Indiana. Environ. Sci. Technol. 2016, 50, 8910-8917. [CrossRef] [PubMed]

25. Mitchell, L.E.; Crosman, E.T.; Jacques, A.A.; Fasoli, B.; Leclair-Marzolf, L.; Horel, J.; Bowling, D.R.; Ehleringer, J.R.; Lin, J.C. Monitoring of greenhouse gases and pollutants across an urban area using a light-rail public transit platform. Atmos. Environ. 2018, 187, 9-23. [CrossRef]

26. Choi, Y.; Vay, S.A.; Vadrevu, K.P.; Soja, A.J.; Woo, J.H.; Nolf, S.R.; Sachse, G.W.; Diskin, G.S.; Blake, D.R.; Blake, N.J. Characteristics of the atmospheric $\mathrm{CO}_{2}$ signal as observed over the conterminous United States during INTEX-NA. J. Geophys. Res. Atmos. 2008, 113, 1-16. [CrossRef]

27. Brenninkmeijer, C.; Crutzen, P.; Boumard, F.; Dauer, T.; Dix, B.; Ebinghaus, R.; Filippi, D.; Fischer, H.; Franke, H.; Frie $\beta$, U.; et al. Civil aircraft for the regular investigation of the atmosphere based on an instrumented container: The new CARIBIC system. Atmos. Chem. Phys. 2007, 7, 4953-4976. [CrossRef]

28. Kort, E.A.; Eluszkiewicz, J.; Stephens, B.B.; Miller, J.B.; Gerbig, C.; Nehrkorn, T.; Daube, B.C.; Kaplan, J.O.; Houweling, S.; Wofsy, S.C. Emissions of $\mathrm{CH}_{4}$ and $\mathrm{N}_{2} \mathrm{O}$ over the United States and Canada based on a receptor-oriented modeling framework and COBRA-NA atmospheric observations. Geophys. Res. Lett. 2008, 35, 1-5. [CrossRef]

29. Cambaliza, M.; Shepson, P.; Bogner, J.; Caulton, D.; Stirm, B.; Sweeney, C.; Montzka, S.; Gurney, K.; Spokas, K.; Salmon, O. Quantification and source apportionment of the methane emission flux from the city of Indianapolis. Elem. Sci. Anth. 2015, 3, 1-18. [CrossRef]

30. Mays, K.L.; Shepson, P.B.; Stirm, B.H.; Karion, A.; Sweeney, C.; Gurney, K.R. Aircraft-based measurements of the carbon footprint of Indianapolis. Environ. Sci. Technol. 2009, 43, 7816-7823. [CrossRef]

31. Bush, S.; Hopkins, F.; Randerson, J.; Lai, C.; Ehleringer, J. Design and application of a mobile ground-based observatory for continuous measurements of atmospheric trace gas and criteria pollutant species. Atmos. Meas. Tech. 2015, 8, 33-63. [CrossRef]

32. Yacovitch, T.I.; Herndon, S.C.; Pétron, G.; Kofler, J.; Lyon, D.; Zahniser, M.S.; Kolb, C.E. Mobile laboratory observations of methane emissions in the barnett shale region. Environ. Sci. Technol. 2015, 49, 7889-7895. [CrossRef]

33. Hurry, J.; Risk, D.; Lavoie, M.; Brooks, B.-G.; Phillips, C.L.; Göckede, M. Atmospheric monitoring and detection of fugitive emissions for Enhanced Oil Recovery. Int. J. Greenh. Gas Control 2016, 45, 1-8. [CrossRef]

34. Tao, L.; Sun, K.; Miller, D.J.; Pan, D.; Golston, L.M.; Zondlo, M.A. Low-power, open-path mobile sensing platform for high-resolution measurements of greenhouse gases and air pollutants. Appl. Phys. B 2015, 119, 153-164. [CrossRef]

35. PCOSC. Tabulation on the 2010 Population Census of the People's Republic of China; China Statistics Press: Beijing, China, 2010.

36. Miao, Y.; Liu, S. Linkages between aerosol pollution and planetary boundary layer structure in China. Sci. Total Environ. 2019, 650, 288-296. [CrossRef] 
37. Miao, Y.; Liu, S.; Guo, J.; Huang, S.; Yan, Y.; Lou, M. Unraveling the relationships between boundary layer height and PM2.5 pollution in China based on four-year radiosonde measurements. Environ. Pollut. 2018, 243, 1186-1195. [CrossRef] [PubMed]

38. Crosson, E. A cavity ring-down analyzer for measuring atmospheric levels of methane, carbon dioxide, and water vapor. Appl. Phys. B 2008, 92, 403-408. [CrossRef]

39. Wang, Y.S.; Zhou, L.; Wang, M.X.; Zheng, X.H. Trends of atmospheric methane in Beijing. Chemosphere Glob. Chang. Sci. 2001, 3, 65-71. [CrossRef]

40. Shen, S.; Yang, D.; Xiao, W.; Liu, S.; Lee, X. Constraining anthropogenic $\mathrm{CH}_{4}$ emissions in Nanjing and the Yangtze River Delta, China, using atmospheric $\mathrm{CO}_{2}$ and $\mathrm{CH}_{4}$ mixing ratios. Adv. Atmos. Sci. 2014, 31, 1343-1352. [CrossRef]

41. Conway, T.; Steele, L. Carbon dioxide and methane in the Arctic atmosphere. J. Atmos. Chem. 1989, 9, 81-99. [CrossRef]

42. Ryoo, J.M.; Iraci, L.T.; Tanaka, T.; Marrero, J.E.; Yates, E.L.; Fung, I.; Michalak, A.M.; Tadic, J.; Gore, W.; Bui, T.P.; et al. Quantification of $\mathrm{CO}_{2}$ and $\mathrm{CH}_{4}$ emissions over Sacramento, California, based on divergence theorem using aircraft Measurements. Atmos. Meas. Tech. 2019, 12, 2949-2966. [CrossRef]

43. Sheng, J.X.; Jacob, D.J.; Turner, A.J.; Maasakkers, J.D.; Sulprizio, M.P.; Bloom, A.A.; Andrews, A.E.; Wunch, D. High-resolution inversion of methane emissions in the Southeast US using SEAC4RS aircraft observations of atmospheric methane: Anthropogenic and wetland sources. Atmos. Chem. Phys. 2018, 18, 6483-6491. [CrossRef]

(C) 2019 by the authors. Licensee MDPI, Basel, Switzerland. This article is an open access article distributed under the terms and conditions of the Creative Commons Attribution (CC BY) license (http://creativecommons.org/licenses/by/4.0/). 